\title{
Role of SME clusters in Bangladesh economy
}

\section{Review}

Michael Porter, ${ }^{1}$ father of the industrial cluster concept defined cluster as a "geographic concentration of interconnected businesses and associated institutions in a particular field". In this definition we are getting three criteria of an industrial cluster. These are (a) A geographic concentration, (b) A group of interconnected business, (c) In a particular field. Beside this fundamental definition industrial cluster could be defined based on common activities, single origin, size of the business, used technology, and focused market or target market etc. Many countries defined clusters based on different criteria for example "One village, one product" or "one town, one industry" concept is very popular in the east like Japan or China. India defined cluster based on a particular number of similar production units in a specific geographical location. The United Nations Industrial Development Organization (UNIDO) defines industrial cluster as a "Geographic and economic concentration of manufacturing activities which produce and sell a domain of interrelated and complementary products and having common problems and opportunities".

There was no official definition of industrial cluster in Bangladesh. For the first timein 2011-12 fiscalyears the Small and MediumEnterprise Foundation (SME Foundation) ${ }^{2}$ took initiative to define $\mathrm{SME}^{3}$ Cluster in Bangladesh. After a thorough discussion with relevant stakeholders like the Bangladesh Bank, ${ }^{4}$ Ministry of Industries, Bangladesh Small and Cottage Industries Corporation, Export Promotion Bureau, and the Federation of Bangladesh Chambers of Commerce and Industries (FBCCI) etc. organizations SME Foundation defined cluster ${ }^{5}$ as "A Cluster is a concentration of enterprises producing similar products or services and is situated within an adjoining geographical location and having a common strengths, weaknesses, opportunities and threats". Key criteria selected to define a SME cluster are; Products or services should be similar or homogenous and related, Enterprises must be production or service units, At least 50 and above production units, Adjoining geographical location: several villages, wards, unions and industrial estates, Scattered within an area of 3-5 kilometer radius.

\section{SME Clusters in Bangladesh}

Based on the above definition SME Foundation identified 177 SME Clusters in 51 districts of Bangladesh. There are maximum 38 Handicrafts \& Miscellaneous clusters followed by 34 AgroProcessing/Agri-business/Plantation clusters, 31 Light Engineering and Metal working clusters, 22 Knitwear \& Readymade Garments clusters, 16 Fashion Rich Effects, Wear \& Consumers Goods clusters, 13 Leather Making \& Leather Goods clusters, 10 Handloom \& Specialized Textiles clusters, 5 Healthcare \& Diagnostics clusters, 3 Plastics \& Other Synthetics clusters, 3 Electronics \& Electrical clusters, and 2 Educational Services clusters in Bangladesh. These clusters are located in 51 different districts of Bangladesh and there are 13 districts namely Netrokona, Rajbari, Narail, Meherpur, Lalmonirhat, Sunamganj, Barguna, Bhola, Patuakhali, Noakhali, Bandarban, Rangamati and Khagrachari where no clusters are found. ${ }^{6}$

There are about 69,902 SME enterprises employing approximately $1,937,809$ workforces in the SME clusters of Bangladesh. Their annual turnover is about BDT 573,510 million per year. ${ }^{7}$ A major portion of government revenue in different forms (Income tax, VAT, Customs duty etc.) comes from these SME clusters. But no significant
Volume 2 Issue 3 - 2018

\author{
Joynal Abdin \\ DCCI Business Institute (DBI), Bangladesh
}

Correspondence: Joynal Abdin, DCCI Business Institute (DBI), Bangladesh, Email mdjoynal@gmail.com

Received: March 27, 2018| Published: June 13, 2018

government support is visible to support, develop or promote SME Clusters/entrepreneurs.

\section{Product producing in SME Clusters}

Major products producing in the SME clusters of Bangladesh are as follows:

1. Agro-Processing/Agri-business/Plantation Clusters: Major products are rice, Brocken rice (commonly known as khud), husking dust (commonly known as kura), burning wood (commonly known as lakri), oil, and oil cake (commonly known as khail) etc.

2. Light Engineering and Metal Working Clusters: Major products are Door and window grille, door and window frame, collapsible gate, iron and steel furniture, Motor parts, engine repair, pump, Machine tools, Agricultural equipment, automobile body building, repairing, and coloring, ship breaking etc.

3. Knitwear and RMG Clusters: Major products are thread, pants, jackets, ladies' three piece sets, towels/gamchas, shirts, tape/ nima, frocks, baby set, suit, and cloths etc.

4. Fashion-rich Wears, effects \& Consumption Goods Clusters: Major products and services are Jewellary made by Gold / Silver / other metals, hair spa, hair protein, party makeup, facial, eyebrow pluck, Herbal facial, haircut, and orange facial etc.

5. Leather and Leather goods clusters: Major products are gent's shoes, ladies shoes, baby shoes, sandal shoes, and Slippers etc.

6. Healthcare \& Diagnostics Clusters: Major services are X-ray, ultra-sonogram, ECG, different pathological tests, hematological tests, biochemical tests, echo-cardiogram, CT scan, and surgery etc.

7. Plastics \& Other Synthetics Clusters: Major products are Mugs, Bowls, Buckets, Bodna, and many other home appliances.

8. Electronics \& Electrical Clusters: Major products are Electrical Board, Switch, Socket, Holder, Cut-out, Anti cut-out, Coil, Battery, TV, Pluspain base, and electric cables etc.

9. Educational Services Clusters: Major services are education services/counseling.

10. Handloom \& Specialized Textiles Clusters: Major products are Blouse, Sari, orna, three piece, farnet, towel, Panjabi, cushion cover, bed sheet, and pillow covers etc. 
11.Handicraft \& Miscellaneous Clusters: Major products are dining table, Mat, Bamboo net, Large bamboo basket (commonly known as Dhol), tabla, Nest, kula, candle stand, cup-plate, clay piggy-bank, flower vase, different dices, mud cover, tub, oil-based perfume, incense sticks, curry and rice cooking pot, bamboo goods, tray set, bowl set, file set, ruler set, cylinder set, and partition set, Wooden Furniture boxed bed, normal bed, dressing table, reading desk, computer desk, Sofa set, dining table, and chairs, etc.

\section{Raw-materials used in SME Clusters}

Major raw materials used in the SME Clusters are rice, wheat, yeast, sugar, salt, husk, sesame, mustered, SS pipe, steel, iron, scrap, GI pipe, aluminum, flat and angle bar, copper, led, color, elastic/ rubber, thread, gum, foam, sticker, lace/ribbon, bale, chemical, cloth, cotton, soda, jori/puti color, zipper, paper, button, , necklace, metal, buckram, fabrics, navy blue RX copper, zinc, acid, sohaga, massage cream, face pack, orange pack, foundation, hair polish, nail polish, spa pack, half silk, herbal pack, beauty pack, Rexene, solution, sole, rubber/elastic, thread, gum, foam, sticker, pasting, gum, synthetic, chemical, plastic, cellulite, animal skin, X-ray film, ECG roll, Ultra sonogram paper, different chemicals, surgical equipment, plastic, uranium powder, steel, plastic, coloring mud, copper, zinc, uranium powder, screw, copper rod, picture tube, remote, steel, carbon, iron, brass, PVC, thread, ribbon/lace, cellulite, wool, half silk, , jori/puti, polyester, color, paper, bamboo, cane, wire, plastic, wood, mud, color mud, soda, date leaf, agar tree, hay and different type of timbers etc. ${ }^{8}$

\section{Challenges of SME Clusters}

SME clusters are mostly naturally grown due to availability of raw materials, skilled labor in competitive price lead by daily needs of local people. There are few clusters growing faster to meet local or international demands, few of the clusters are going to be abolished due to wrong government policy, or absence of necessary support from the government. Clusters ${ }^{9}$ are playing a vital role in employment generation and balanced development of the country but till now they are neglected by the governments or donors in terms of policy support, technology development, infrastructure development, and electricity and other utilities supply, market linkage with local or foreign buyers. Development barriers of SME Clusters are very much location specific and sector dependent. There for it is quite difficult to describe challenges of SME Clusters in a particular document or article. With this limitation in mind we could describe major challenges of Bangladeshi SME Clusters as follows:

Absence of appropriate technology: Most of the clusters are using old technology adopted in $1950-60$ s. Therefore productivity of the clusters is lower than that of their competitors. It result on the quality of the products is inferior. Entrepreneurs are losing market share to imported products or failing to get market access in target market at home and abroad. For example; entrepreneurs of the Coconut Oil Cluster located at Bagherhat Sadar are using a semi auto technology imported from Japan in 1952. Local workshops were copied it and producing the same machine during last 60 years. Major limitation of this machine is that, it is unable to extract $100 \%$ oil from the coconut and quality of the oil produced is crude graded. Till now there is no refinery machine at Bagherhat Coconut Oil Cluster as a result their oil is losing market share to imported coconut oil marketing by various multinationals in Bangladesh. Similarly; hundred years old technology is using at Sataranji Cluster at Nishbetgaonj, Rongpur and different handloom clusters all over the country.
Inadequate raw materials supply in justified price: Most of the clusters are dependent on imported raw materials or purchased raw materials from a third party. There are middlemen / intermediary traders / importers in each of the sectors supplying raw materials to the clusters. ${ }^{10}$ Sometime these intermediaries used to charge illogical price of the raw materials without any valid reason. For example; there are more than five thousands electrical and plastic goods manufacturing enterprises in Bangladesh. Raw materials of these sectors are mainly import dependent or recycle based. Small entrepreneurs of the sector could not import raw materials directly due to their limited financial and technical ability. They used to purchase raw materials from local trader / importers. In few cases importers used to charge so higher price of raw materials which is not justifiable with the international market. Syndication is responsible for this unusual price hick in these sectors. Not only in plastic or electrical sector same scenario is happening with the handloom or power loom entrepreneurs in home textile cluster at Kumarkhali, Kustia and Hosiary cluster at Gobindagaong, Gaibandha while they used to purchase threads or dye. These irrational price hicks of raw materials make the whole sector uncompetitive in the market. A large number of entrepreneurs, workers have to suffer to give undue cost of raw materials into the pocket of a fractional number of middlemen.

Absence of modern designing knowledge and technology: Most of the SME clusters in Bangladesh are using old technologies and producing almost similar products throughout their life. On the other hand customer's choice is changing every day and they are not willing to purchase the same design, same quality or same shaped products with a higher price. As a result they are attracting by the imported good looking products even lower quality products with higher price. Limited deign knowledge and technology is a common problem in almost all the SME Clusters in Bangladesh.

Absence of testing facility: Testing products is a prerequisite to classify or grading up the products. But we have absence of testing facility in almost every cluster in Bangladesh. For example there are no testing machines in Bangladesh to test quality of Agar - Ator producing at Agar Ator Cluster located at Barolekha, Moulvibazar. Gold testing facilities is very rare in any Jewelry clusters in Bangladesh, Wood seasoning and testing facility of the wood producing Cricket Bat is absent in Baldia Cricket Bat Cluster at Nesarabad, Pirojpur. Without out a very limited cluster this is a common problem everywhere in Bangladesh.

Access to finance: Access to finance is one of the oldest problems for Bangladeshi entrepreneurs either in any cluster or outside. So many initiatives were taken by the central bank to facilitate access to finance at door step of the entrepreneurs. But till now it is a major challenge for any new entrepreneur or unable to pay mortgage. But today we will see sector specific or location specific format of the same problem in different forms. For example entrepreneurs of Bhairab shoe clusters faces a dry season for three months in every year. At that point of time their product reaches lowest sales and lowest revenue generation. As a result they are unable to pay bank installment during that period. But they are willing to pay whole year's installment in rest eight months. But no bank is offering that tailor made loan products to them to address their ground reality. Entrepreneurs of Agar-Ator Cluster located at Barolekha, Moulvibazar are getting bank loan for BDT 5-50 lac easily. But they need up to BDT 10 - 20 Crore while government Agar garden / forest used to call for tender. If a third party (do not have ator producing plant) win in the tender then either original entrepreneurs having Ator producing factories 
have to purchase the trees with much higher price or the tree will be exported to neighboring country. Thus Bangladesh losses its own wealth to add value and export in a much higher price. There are no banks who can give that BDT 10-20 Crore loan for a shortest period of time to the Agar-Ator entrepreneurs at Barolekha Agar Ator Cluster at Moulvibazar. Another unique form of this access to finance problem could be seen at Nawgah Jewelry Cluster, Banks usually do not provide loan to Jewelry business. Though our nearest neighbor India is exporting Jewelry products worth of millions of Dollars to Dubai and other Middle East countries. Till now Bangladesh government is not providing any support to Jewelry sector. Even official import of gold is banned or strictly controlled by our government. On the other hand Bangladesh is importing a significant amount of artificial Jewelry / stone Jewelry from India and China to meet its internal demand.

Lack of knowledge about product's quality and quality certification: Our entrepreneurs have very limited knowledge about product's quality and international quality certification system. As a result they are lagging behind even with qualitative products in few sectors.

Limited number of skilled labor and absence of qualified technicians: Most of the clusters have potentials to grow further but availability of skilled manpower is very limited. As a result labor turnover is higher and entrepreneurs are not willing to develop skills with their own cost. Entrepreneurs are not adopting new technologies due to not available of technicians of modern machineries in local market. As a result productivity and quality of products is not increasing up to a satisfactory level.

Non-cooperation from relevant government agencies: In most of the cases Tax-VAT, police, environment, consumer rights etc. officials are not cooperating with the entrepreneurs. There could have an orientation gap between these officials and entrepreneurs. Government could orient these officials that, all entrepreneurs are not dishonest so everybody shall not be treated as a thief. They must remember an entrepreneur's role in the economy by paying taxes / VAT, generating employment and increasing GDP growth of the country. ${ }^{11}$

\section{Way forward}

So many development projects are being implementing by the government, donor agencies and NGOs in different sectors of Bangladesh. There could be a development project to update existing technologies of different SME clusters to increasing productivity and products quality. ${ }^{12}$ Government could allow sectoral associations to import raw materials relevant to that sector with bonded warehouse facility to facilitate export of SME products producing in different SME clusters throughout the country. Government may consider allowing minimum import duty on raw materials using in SME clusters and give protection of SME products against importing. The central bank have to inspire the scheduled commercial banks to offer tailor made loan products based on local needs in different SME Clusters. Government has to take the lead in establishing sector specific testing laboratories and training institutes to promote world class product and efficient labor / technicians in Bangladeshi business arena. Today or tomorrow we have to face the ground reality that, without producing qualitative products having international standard certification no one will buy our products at home or abroad. Therefor government could inspire entrepreneurs to achieve global standard quality certification for respective products.

Moreover cluster development activities shall get priority in government development agenda for balance development of Bangladesh. At this stage SME clusters ${ }^{13}$ are in need of government's intervention for prompt growth and sustainable development. It will facilitate industrialization, employment, poverty reduction, increase in export earnings, and balanced development of each district of Bangladesh. Government shall not control industrialization may be anywhere without ensuring proper facilities into a particular location. Otherwise we will see that no natural clusters are growing due to extreme government controlling mechanism. It could increase our import dependency in many sectors.

\section{Acknowledgments}

None.

\section{Conflict of interest}

Author declares there is no conflict of interest.

\section{References}

1. Porter ME. The Economic Performance of Regions. Regional Studies. 2003;37(6):549-578.

2. Small and Medium Enterprise Foundation. SME Clusters in Bangladesh. 2013.

3. Abdin MJ. SMEs and our development goals published by the Daily Star 2017.

4. Bangladesh Bank, Small and Medium Enterprise (SME) Credit Policies \& Programmes.

5. Foundation for MSME Clusters, Pro-poor Cluster Development Methodology. 2010.

6. Otsuka K, Sonobe T. A Cluster-Based Industrial Development Policy for Low-Income Countries. GRIPS Discussion Paper 11-09, Tokyo, Japan; 2011

7. UNIDO, SME Clusters and Responsible Competitiveness in Developing Countries. 2006.

8. Williams IF. Cluster Development: The How, TCI Annual Conference, Hong Kong. 2005.

9. Murali BP, Banerjee S. Fostering Responsible Behavior in MSMEs in Clusters: Role of Cluster Development Agent, Volume. III, Foundation for MSME Clusters, 2011.

10. Maxwell Stamp Plc. Prepared for the Ministry of Economy, Labor and Entrepreneurship (MELE), and the Central Finance and Contracting Agency (CFCA), Government of the Republic of Croatia, Guidelines for Cluster Development A Handbook for Practitioners. 2013.

11. World Bank, Cluster for Competitiveness-A Practical Guide \& Policy Implications for Developing. Cluster Initiatives. 2009

12. Gamp TL, Köcker GM, Nerger M, et al. Cluster Collaboration and Business Support Tools to Facilitate Entrepreneurship, Cross-sectoral Collaboration and Growth. European Cluster Observatory. 2014.

13. Choe K, Roberts B. Competitive Cities in 21st Century: Cluster based local economic development. Urban Development Series, ADB, 2011. 